解 説

\title{
MIM Parts for Automotive Applications Production and Economic Aspects
}

\author{
Detlef Gonia \\ GKN Sinter Metals, SIGMA Bldg. 1F, 3-7-12 Shibaura Minato-ku, Tokyo 108-0023.
}

Received December 14, 1998

\section{SYNOPSIS}

Due to the improvements in the production process for metal injection molding (MIM) parts produced by this method, especially light weight parts with very complex shape have become very competitive against other technologies. The introduction of the catalytic debinding process is an important improvement since it decreases the debinding time greatly and allows the use of a continuous process, in which debinding as well as sintering is performed in one furnace. MIM parts for automotive applications can be found increasingly at least on the European market. KEY WORDS

metal injection molding, catalytic debinding, debinding time, continuous process, automotive application

\section{Introduction}

MIM technology capable of being used in mass production is available since the $1980^{\prime} \mathrm{s}^{33}$. Metal injection molding allows the realization of complex shaped parts similar to the plastic molding process. Some other advantages are the low surface roughness of the parts and the density which is close to full density and thus significantly higher than in conventional powder metallurgy (PM).

Many applications for MIM parts are found in watches, office machines, electrical and communication equipment as well as in medical equipment and parts for general industry. There are of course also automotive applications, but it seems that on the Japanese market there is only a small percentage of automotive-related parts up to now ${ }^{1,4)}$.

GKN Sinter Metals has started to produce MIM parts in 1988, and since around 1992 automotive applications have broadened the range of parts, which in the beginning was limited to parts for printers and copy-machines.

\section{Production Aspects}

The basic production steps in MIM are the preparation of the feedstock which contains the metal powder and the binder, the molding, the debinding and the sintering of the part.

In the beginning the thermal debinding process of MIM parts was very common, with the disadvantage of long cycle times. In addition to that the thermal debinding process requires usually dedicated batch-type furnaces. An alternative to the thermal debinding is the catalytic debinding, used in our company since 1991. The principle of catalytic debinding is that one component of the binder consists of Polyacetals. Polyacetals are subject to decomposition by acids below their heat distortion temperature, and thus the green part is first treated in a $\mathrm{N}_{2}$ atmosphere containing some percent of Nitric Acid $\left(\mathrm{HNO}_{3}\right)$ at comparatively low temperatures of around $140{ }^{\circ} \mathrm{C}^{5}$. During this first debinding step a porous brown body is created, ready for the 2 nd, thermal debinding process. Altogether the catalytic debinding process is much faster than the conventional thermal debinding process. Some care has to be taken concerning a proper wastegas deburning, so that no harmful substances escape into the environment.

The catalytic debinding process with all the described steps permits a continuous process which includes also the subsequent sintering in a dedicated walking beam furnace ${ }^{6 \prime}$. Since 1995 GKN Sinter Metals uses such a "MIM Master" walking beam furnace with an integrated burn-out zone, and the use of it has increased the cost-competetiveness considerably. The sintering temperature can vary between $1250^{\circ} \mathrm{C}$ and $1390^{\circ} \mathrm{C}$, and the used atmospheres can either be mixed gas $\left(\mathrm{N}_{2} / \mathrm{H}_{2}\right)$ or pure hydrogen $\left(\mathrm{H}_{2}\right)$. This applies to the full scale production of all steel parts.

Parts made of special materials like stainless steel or superalloys are sintered in a separate batch-type vacuum furnace. 


\section{Economic Aspects}

The weight of MIM parts is low, compared with conventional PM parts and is generally in the range of a few grams up to around 100 grams, although in recent

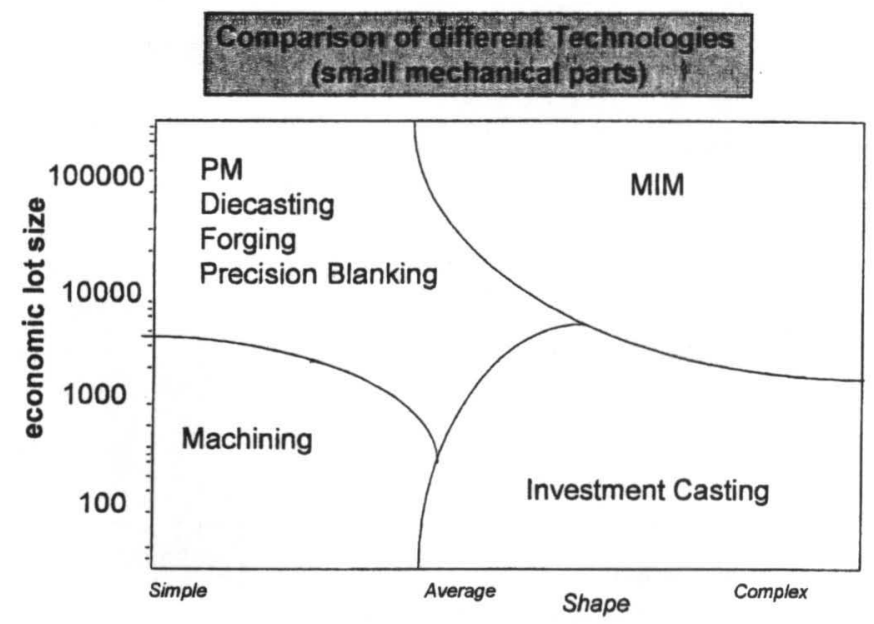

Fig.1 Comparison of different Technologies (small mechanical parts). developments parts of up to almost $1 \mathrm{~kg}$ weight are under development ${ }^{2}$. But these are exceptions. Because of the high price of powders suitable for the MIM process, generally small MIM parts are cost-competitive. The debinding time increases with increased wall-thickness, thus limiting the cost-competitiveness of the MIM-process once again generally to smaller parts.

Comparing the next production steps of conventional PM and MIM the following applies: The molding step requires a powder press for conventional parts which is 2 to several times more expensive than the injection molding machine in the case of MIM. The tool cost for parts of comparable size would probably not differ very much, however in the case of MIM more than one part ( 4 or also more) can be molded with one shot, thus increasing the productivity.

Depending on the used debinding process a special debinding furnace may be necessary for the MIM-process, not needed for conventional PM. If a combined debindingsintering furnace is used, then the cycle time can be greatly reduced, but it still remains longer than for conventional

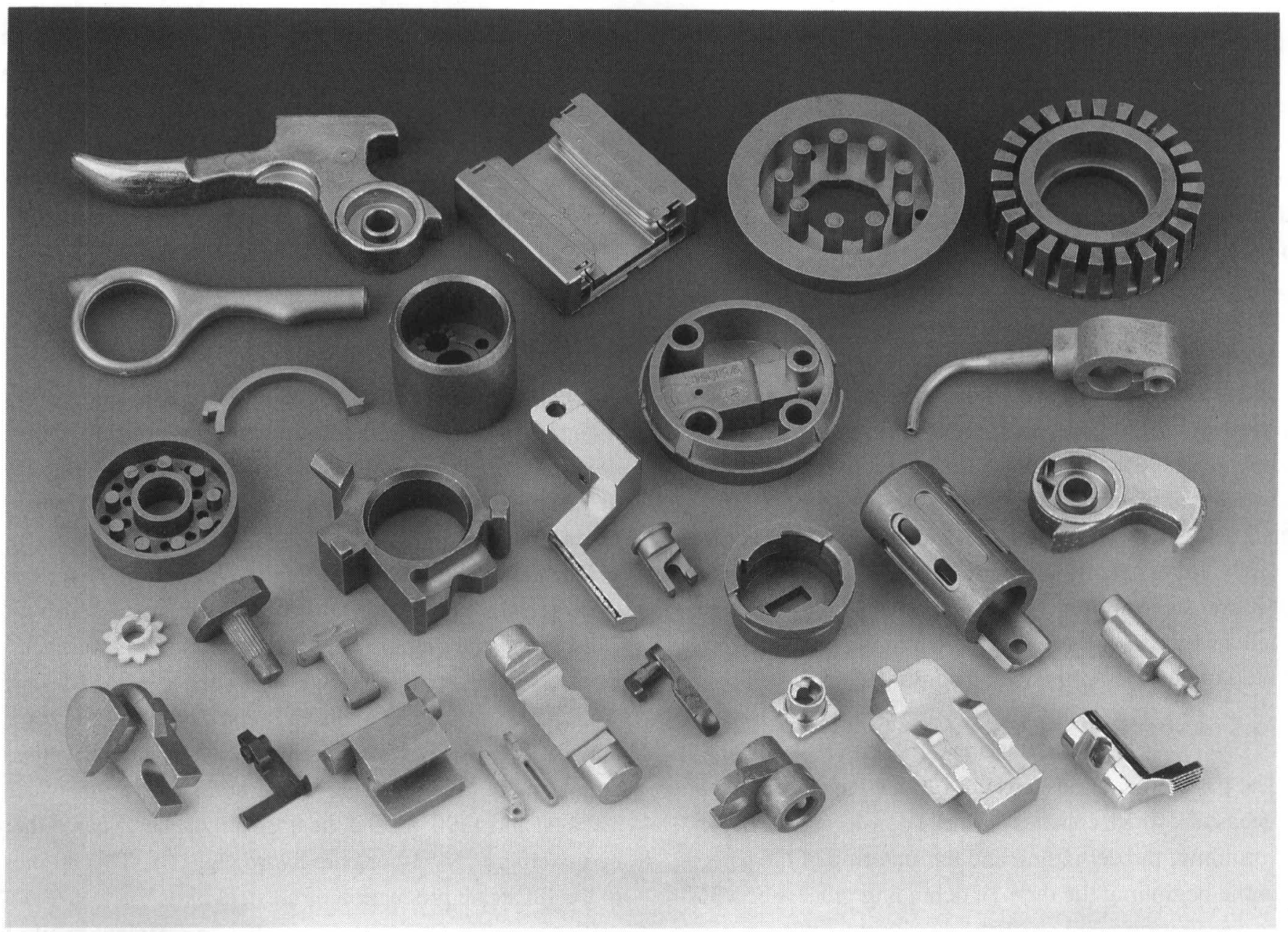

Fig.2 Various MIM parts, including automotive applications. 
PM. In addition to that the investment cost for the combined debinding-sintering furnace for MIM is higher than that of a normal walking beam furnace for PM.

Table 1 Economic Considerations PM versus MIM.

\begin{tabular}{|l|l|l|}
\hline Point & $\boldsymbol{P M}$ & $\boldsymbol{M I M}$ \\
\hline Material cost & 0 &,$-(--)$ \\
\hline $\begin{array}{l}\text { Molding machine } \\
\text { investment cost }\end{array}$ & - & 0 \\
\hline Molding productivity & 0 & $\begin{array}{l}+, \\
(++)\end{array}$ \\
\hline Debinding time & ++ & - \\
\hline $\begin{array}{l}\text { Investment cost } \\
\text { sintering furnace(s) }\end{array}$ & 0 & - \\
\hline
\end{tabular}

\section{Applications}

For automotive applications the used materials are often $\mathrm{Fe}-2 \% \mathrm{Ni}, \mathrm{Fe}-0.4 \% \mathrm{C} 1 \% \mathrm{Cr} 0.75 \% \mathrm{Mn} 0.2 \% \mathrm{Mo}$ (SAE 4140 ) and also $\mathrm{Fe}-0.2 \% \mathrm{C} 0.5 \% \mathrm{Cr} 0.6 \% \mathrm{Mn} 0.5 \% \mathrm{Ni}$ (SAE 8620 ), in some rare cases stainless steel is used. Compared with conventional PM materials, density and elongation are high. As a result, case hardening and surface treatment can be applied, and also brazing is no problem for MIM parts (Table 2). It seems however that MIM is not fiercely competing with conventional PM, but rather with machining and investment casting. In some cases MIM parts have also substituted plastic injection molded parts due to their superior mechanical properties, nevertheless offering similar complexity of shape (Table 3 ).

Some examples for the areas where MIM-parts are used in cars are the gear box, the engine, the braking system, the heating system and the "folding top" of a convertible car (Table 2).

Table 2 MIM Parts for Automotive Applications.

\begin{tabular}{|c|c|c|c|}
\hline Part name & Material & Weight (g) & Application / Point \\
\hline $\begin{array}{l}\text { Ignition } \\
\text { chamber }\end{array}$ & Stainless steel (316 L) & 43 & $\begin{array}{l}\text { Installed in an optional heating system of a } \\
\text { car, needs to be gas-tight, braze-able and } \\
\text { corrosion resistant }\end{array}$ \\
\hline Ratchet lever & $\begin{array}{l}\mathrm{Fe}-2 \% \mathrm{Ni} \text {, zinc coated } \\
\text { and also chromate } \\
\text { coated }\end{array}$ & 41 & $\begin{array}{l}\text { For the actuation of the foldable top of a } \\
\text { convertible car, replaces an injection } \\
\text { molded plastic part }\end{array}$ \\
\hline Ratchet & $\begin{array}{l}\mathrm{Fe}-2 \% \mathrm{Ni} \text {, zinc coated } \\
\text { and also chromate } \\
\text { coated }\end{array}$ & 17 & 11 \\
\hline Oil nozzle & $\mathrm{Fe}-2 \% \mathrm{Ni}$ & $\begin{array}{l}9 \text { (without } \\
\text { tube) }\end{array}$ & $\begin{array}{l}\text { For cooling the pistons in a V-8 engine, } \\
\text { tube soldered into a cross-hole }\end{array}$ \\
\hline Tie rod & $\begin{array}{l}\mathrm{Fe}-0.4 \% \mathrm{C} 1 \% \mathrm{Cr} \\
0.75 \% \mathrm{Mn} 0.2 \% \mathrm{Mo}, \\
\text { quenched and tempered }\end{array}$ & 30 & $\begin{array}{l}\text { In the parking brake of a car, for } \\
\text { automatical wear adjustment }\end{array}$ \\
\hline $\begin{array}{l}\text { Synchronizer } \\
\text { actuator disc }\end{array}$ & $\mathrm{Fe}-2 \% \mathrm{Ni}$, case hardened & 15 & $\begin{array}{l}\text { Allows the usage of the synchronization of } \\
\text { the } 5 \text { th speed for the reverse gear, together } \\
\text { with other parts, in a dedicated } \\
\text { mechanism, thus making a synchronization } \\
\text { for the reverse gear obsolete }\end{array}$ \\
\hline Lever & $"$ & 2.4 & $" 1$ \\
\hline Pin & $"$ & 2 & $"$ \\
\hline Dust cover & $\begin{array}{l}\mathrm{Fe}-0.4 \% \mathrm{C} 1 \% \mathrm{Cr} \\
0.75 \% \mathrm{Mn} 0.2 \% \mathrm{Mo} \\
\text { quenched and tempered }\end{array}$ & 11 & Covers the door lock of a passenger car \\
\hline
\end{tabular}


Table 3 Competitive Situation.

\begin{tabular}{|l|l|l|}
\hline Part name & Competing technology & Why MIM part \\
\hline Ignition chamber & Investment casting & $\begin{array}{l}\text { Lower price than investment casting, } \\
\text { no subsequent machining needed }\end{array}$ \\
\hline Ratchet lever & $\begin{array}{l}\text { Plastic injection } \\
\text { molding }\end{array}$ & Material strength \\
\hline Ratchet & $\begin{array}{l}\text { Plastic injection } \\
\text { molding }\end{array}$ & Material strength \\
\hline Oil nozzle & PM & $\begin{array}{l}\text { Lower price, Cross hole requires } \\
\text { machining in the case of PM }\end{array}$ \\
\hline Tie rod & $?$ & Lower price \\
\hline $\begin{array}{l}\text { Synchronizer actuator } \\
\text { disc }\end{array}$ & Investment casting & Lower price, higher precision \\
\hline Lever & $?$ & Lower price, higher precision \\
\hline Pin & $?$ & Lower price, higher precision \\
\hline Dust cover & $?$ & Lower price \\
\hline
\end{tabular}

References

1) Y.Kato: "Ultrafine Powder for Metal Injection Molding (MIM) of Automobile Parts", Powder Metallurgy in Automotive Applications, Editor P.Ramakrishnan, Oxford \& IBH Publishing Co. PVT. LTD. New Delhi and Calcutta, 295-303.

2) K.F.Hens, T.J.Roche and J.A.Grohowski: "Expanding the Capabilities for MIM: Ultra High Precision PIM, Miniature and Large Component PIM", Proceedings of PIM-97, 1st European Symposium on Powder Injection Moulding, European Powder Metallurgy Association, 208-219.

3) O.A.Zitzmann, K.F.Hens and J.A.Grohowski: "A Synopsis of Patents in Powder Injection Molding",
Proceedings of PIM-97, 1st European Symposium on Powder Injection Moulding, European Powder Metallurgy Association, 258-260.

4) Y.Kato: "MIM Trends in Asia", PIM-97 Plenary Session, Proceedings of PIM-97, 1st European Symposium on Powder Injection Moulding, European Powder Metallurgy Association, 2-16.

5) "Catamold®, New directions for Powder Injection Molding", company brochure, BASF Aktiengesellschaft, 67056 Ludwigshafen, Germany, 1998.

6) "Industrial Furnace Equipment for Metal Injection Molding", company brochure, Cremer Thermoprozessanlagen $\mathrm{GmbH}$, Auf dem Flabig, D-52355 Düren, Germany, 1998. 